\title{
Nutrient Requirements, Leaf Tissue Standards, and New Options for Fertigation of Northern Highbush Blueberry
}

\author{
David R. Bryla ${ }^{1,3}$ and Bernadine C. Strik ${ }^{2}$
}

AdDITIONAL INDEX WORDs. Vaccinium corymbosum, ammonium-nitrogen, fertilizer, humic acids, organic, soil $\mathrm{pH}$

SUMMARY. Northern highbush blueberry (Vaccinium corymbosum) is well adapted to acidic soils with low nutrient availability, but often requires regular applications of nitrogen $(\mathrm{N})$ and other nutrients for profitable production. Typically, nutrients accumulate in the plant tissues following the same pattern as dry matter and are lost or removed by leaf senescence, pruning, fruit harvest, and root turnover. Leaf tissue testing is a useful tool for monitoring nutrient requirements in northern highbush blueberry, and standards for analysis have been updated for Oregon. Until recently, most commercial plantings of blueberry (Vaccinium sp.) were fertilized using granular fertilizers. However, many new fields are irrigated by drip and fertigated using liquid fertilizers. Suitable sources of liquid $\mathbf{N}$ fertilizer for blueberry include ammonium sulfate, ammonium thiosulfate, ammonium phosphate, urea, and urea sulfuric acid. Several growers are also applying humic acids to help improve root growth and are injecting sulfuric acid to reduce carbonates and bicarbonates in the irrigation water. Although only a single line of drip tubing is needed for adequate irrigation of northern highbush blueberry, two lines are often used to encourage a larger root system. The lines are often installed near the base of the plants initially and then repositioned 6-12 inches away once the root system develops. For better efficiency, $\mathbf{N}$ should be applied frequently by fertigation (e.g., weekly), beginning at budbreak, but discontinued at least 2 months before the end of the growing season. Applying $\mathbf{N}$ in late summer reduces flower bud development in northern highbush blueberry and may lead to late flushes of shoot growth vulnerable to freeze damage. The recommended $\mathrm{N}$ rates are higher for fertigation than for granular fertilizers during the first 2 years after planting but are similar to granular rates in the following years. More work is needed to develop fertigation programs for other nutrients and soil supplements in northern highbush blueberry.

$\mathrm{B}$ ueberry has lower nutrient requirements than most crops and thrives in acidic soils $(\mathrm{pH}$ of 4.5-5.5) with limited availability of

This paper was part of the colloquium, "Recent Advances in Perennial Berry Crop Nutrition and Directions for Future Research," held on 28 July 2014 at the ASHS Annual Conference in Orlando, FL, and sponsored by the Viticulture and Small Fruit Working Group.

We appreciate the funding support provided by the Oregon and Washington Blueberry Commissions and the Northwest Center for Small Fruits Research, and thank Amanda Vance, Faculty Research Assistant, the graduate students who have worked in northern highbush blueberry nutrition (Oscar Vargas, Pilar Bañados, and Handell Larco), and our grower collaborators

Mention of trademark, proprietary product, or vendor does not constitute a guarantee or warranty of the product by the U.S. Department of Agriculture and does not imply its approval to the exclusion of other products or vendors that also may be suitable.

${ }^{1}$ U.S. Department of Agriculture, Agricultural Research Service, 3420 Northwest Orchard Avenue, Corvallis, OR 97330

${ }^{2}$ Department of Horticulture, Agricultural and Life Science Building 4009, Oregon State University, Corvallis, OR 97331

${ }^{3}$ Corresponding author. E-mail: david.bryla@ars.usda. gov. essential nutrients such as nitratenitrogen $\left(\mathrm{NO}_{3}-\mathrm{N}\right)$, phosphorus $(\mathrm{P})$, potassium $(\mathrm{K})$, calcium $(\mathrm{Ca})$, and magnesium $(\mathrm{Mg})$ (Korcak, 1988). However, despite the plant's ability to subsist with little to no fertilizer, a good fertilization program is necessary for rapid plant growth and highquality fruit production (Hanson and Hancock, 1996; Hart et al., 2006).
Nitrogen is the primary nutrient applied to blueberry and is required each year. Unlike most crops, blueberry acquires primarily the ammonium $\left(\mathrm{NH}_{4}\right)$ form of $\mathrm{N}$ over $\mathrm{NO}_{3}-\mathrm{N}$, due to low nitrate reductase activity in the roots and leaves (Merhaut and Darnell, 1995; Peterson et al., 1988). When the plants are low in $\mathrm{N}$, shoot growth is poor, and the leaves turn pale green or yellow (chlorotic) and often develop a reddish tinge. Other nutrients that are often applied to blueberry include $\mathrm{P}, \mathrm{K}, \mathrm{Ca}, \mathrm{Mg}$, elemental sulfur [ $S$ (which is used to lower soil $\mathrm{pH})$ ], iron (Fe), boron $(\mathrm{B})$, copper $(\mathrm{Cu})$, and zinc $(\mathrm{Zn})$ (Hanson and Hancock, 1996; Hart et al., 2006). Manganese ( $\mathrm{Mn})$ is also required by the plants but is typically available in abundance under acidic soil conditions (Korcak, 1988). See Caruso and Ramsdell (1995) for useful illustrations of nutrient deficiencies and toxicities in northern highbush blueberry.

Traditionally, northern highbush blueberry fields have been fertilized using granular fertilizers. The current recommendation for Oregon is to split granular $\mathrm{N}$ fertilizers into thirds, with the first application in late April, the second in mid-May, and the third in mid-June, at rates varying from 50 to $165 \mathrm{lb} /$ acre $\mathrm{N}$ in plantings mulched with sawdust, depending on the age of the planting (Hart et al., 2006). These recommendations are practiced by northern highbush blueberry growers throughout the United States and elsewhere and are applicable to fields irrigated by sprinklers. However, many new fields are irrigated through drip systems. In addition to using less water, a major advantage of drip irrigation is the ability to fertigate.

\begin{tabular}{llll}
\hline $\begin{array}{l}\text { Units } \\
\begin{array}{l}\text { To convert U.S. to SI, } \\
\text { multiply by }\end{array}\end{array}$ & U.S. unit & SI unit & $\begin{array}{l}\text { To convert SI to U.S., } \\
\text { multiply by }\end{array}$ \\
\hline 0.4047 & $\mathrm{acre}(\mathrm{s})$ & $\mathrm{ha}$ & 2.4711 \\
0.3048 & $\mathrm{ft}$ & $\mathrm{m}$ & 3.2808 \\
0.0283 & $\mathrm{ft}^{3}$ & $\mathrm{~m}^{3}$ & 35.3147 \\
2.54 & inch(es) & $\mathrm{cm}$ & 0.3937 \\
0.4536 & $\mathrm{lb}$ & $\mathrm{kg}$ & 2.2046 \\
1.1209 & $\mathrm{lb} / \mathrm{acre}$ & $\mathrm{kg} \cdot \mathrm{ha}^{-1}$ & 0.8922 \\
0.1198 & $\mathrm{lb} / \mathrm{gal}$ & $\mathrm{kg} \cdot \mathrm{L}^{-1}$ & 8.3454 \\
0.5000 & $\mathrm{lb} / \mathrm{ton}$ & $\mathrm{kg} \cdot \mathrm{Mg}^{-1}$ & 2.0000 \\
1 & $\mathrm{micron}(\mathrm{s})$ & $\mu \mathrm{m}$ & 1 \\
28.3495 & $\mathrm{oz}$ & $\mathrm{g}$ & 0.0353 \\
70.0532 & $\mathrm{oz} / \mathrm{acre}$ & $\mathrm{g} \cdot \mathrm{ha}^{-1}$ & 0.0143 \\
31.2500 & $\mathrm{oz} / \mathrm{ton}$ & $\mathrm{g} \cdot \mathrm{Mg}^{-1}$ & 0.0320 \\
2.2417 & ton $(\mathrm{s}) / \mathrm{acre}$ & $\mathrm{Mg} \cdot \mathrm{ha}^{-1}$ & 0.4461 \\
$\left({ }^{\circ} \mathrm{F}-32\right) \div 1.8$ & ${ }^{\circ} \mathrm{F}$ & ${ }^{\circ} \mathrm{C}$ & $\left({ }^{\circ} \mathrm{C} \times 1.8\right)+32$
\end{tabular}


Fertigation is the practice of applying soluble fertilizers to the plants directly through the irrigation system (Kafkafi and Tarchitsky, 2011). Most of the roots of a drip-irrigated plant are located near the drip emitters, and, therefore, nutrient application through the drip system is a very efficient way to apply the fertilizer (Bryla, 2011). Several advantages of fertigation include reduced delivery costs (no need for tractors or spreaders), greater control of where and when the fertilizers are placed, the ability to target application of specific nutrients during particular stages of crop development, and the potential to reduce fertilizer losses by supplying only small amounts of fertilizer to the plants as needed. However, disadvantages include the costs associated with the need for higher fertilizer quality (i.e., purity and solubility) and the capital costs of the equipment required to inject the fertilizer through the irrigation system. System costs are even higher when injection of corrosive materials such as sulfuric acid and acidified fertilizers are needed (see "Fertilizer products available for fertigation").

Recently, Vargas and Bryla (2015) compared the differences between fertigation and granular fertilizer using different sources of $\mathrm{N}$ fertilizer during the first 5 years of fruit production in 'Bluecrop' northern highbush blueberry. Soil pH was slightly lower with granular fertilizers than with fertigation; however, leaf $\mathrm{N}$ was also lower with granular fertilizer, whereas yield was greatest when plants were fertigated using ammonium sulfate or urea sulfuric acid (Table 1). Ehret et al. (2014) found similar results with 'Duke' northern highbush blueberry in British Columbia and concluded that fertigation produced greater yields with less $\mathrm{N}$ than broadcast applications of the fertilizer. In both cases, the results indicated that northern highbush blueberry was well suited to fertigation. Higher rates of $\mathrm{N}$ fertilizer likewise increased plant growth in both of these studies but did not improve yield in any year and reduced berry size during the first few years of fruit production. Whether $\mathrm{N}$ was applied by fertigation or as granular fertilizer, only $67-93 \mathrm{~kg} \cdot \mathrm{ha}^{-1} \mathrm{~N}$ or less was needed per year to optimize fruit production.

The purpose of this article is to review recent information on nutrient

Table 1. Comparison of granular and liquid nitrogen $(\mathrm{N})$ fertilizers on soil $\mathrm{pH}$, leaf $\mathrm{N}$, and yield of 'Bluecrop' northern highbush blueberry in western Oregon (adapted from Vargas and Bryla, 2015).

\begin{tabular}{lccc}
\hline Fertilizer & $\frac{\text { Soil }}{\mathrm{pH}}$ & $\frac{\text { Leaf } \mathrm{N}}{(\%)^{\mathrm{z}}}$ & $\frac{\text { Yield }}{(\text { tons/acre })^{\mathrm{y}}}$ \\
$\begin{array}{l}\text { No fertilizer } \\
\text { Granular fertilizer }\end{array}$ & $6.2 \mathrm{a}^{\mathrm{x}}$ & $1.29 \mathrm{~d}$ & $15 \mathrm{c}$ \\
$\quad$ Ammonium sulfate & $5.1 \mathrm{c}$ & $1.67 \mathrm{bc}$ & $22 \mathrm{~b}$ \\
$\quad$ Urea & $5.6 \mathrm{~b}$ & $1.60 \mathrm{c}$ & $24 \mathrm{ab}$ \\
Fertigation & & & \\
$\quad$ Ammonium sulfate & $5.3 \mathrm{c}$ & $1.78 \mathrm{a}$ & $28 \mathrm{a}$ \\
$\quad$ Urea & $5.8 \mathrm{~b}$ & $1.65 \mathrm{~b}$ & $25 \mathrm{ab}$ \\
$\quad$ Urea sulfuric acid & $5.6 \mathrm{~b}$ & $1.70 \mathrm{ab}$ & $27 \mathrm{a}$ \\
\hline
\end{tabular}

${ }^{\mathrm{z}}$ Leaf $\mathrm{N}$ concentrations are considered normal at $1.76 \%$ to $2.00 \%$, below normal at $1.50 \%$ to $1.75 \%$, and deficient at $<1.50 \%$ (Hart et al., 2006).

y Total cumulative yield during the first 5 years of fruit production $(2008-12)$; 1 ton $/$ acre $=2.2417 \mathrm{Mg} \cdot \mathrm{ha}^{-1}$

${ }^{x}$ Means followed by a different letter within a column are significantly different at $P \leq 0.05$, according to Tukey's honestly significant difference test.

requirements in northern highbush blueberry and discuss the latest options for fertigation by drip in commercial production systems. The article also contains updated standards for leaf tissue testing of northern highbush blueberry that were developed from a recent evaluation of nutrients in common cultivars growing in conventional and certified organic fields in western Oregon.

\section{Nutrient requirements}

Plant Development. In most cases, accumulation of nutrients in each plant part follows the same pattern as dry matter in northern highbush blueberry (Bryla et al., 2012). Typically, the plants are propagated from cuttings or by tissue culture and transplanted to the field after $\approx 18$ months in the nursery. Shoot growth begins in the spring with bud swell and is quickly followed by flowering. The shoots grow in flushes, rapidly producing 3-12 inches of new shoot growth with each flush, depending on shoot location and orientation; each flush ends with apical bud abortion ("black tip" stage). Each shoot may have one to several flushes of growth during the season. New canes or whips are the primary "renewal" wood for subsequent fruit production and develop throughout the season from the base (crown) of the plants or from latent buds from older wood higher up on the bush. To improve establishment of the plants, flower buds are usually removed by pruning during the first or second year after planting to prevent competing sinks from fruit production (Strik and Buller, 2005).
Depending on the cultivar and growing region, the fruit require anywhere from 2 to 4 months to develop and are usually harvested by hand or machine over a period of 2-4 weeks. Root growth has been shown to peak before budbreak and after fruit harvest (Abbott and Gough, 1987). Most of the roots are very fine (40$75 \mu \mathrm{m}$ in diameter) and are often colonized by mycorrhizal fungi (Valenzuela-Estrada et al., 2008). The roots do not penetrate very deeply and are usually confined to the top 12-18 inches in most soils (Bryla and Strik, 2007).

NUTRIENT UPTAKe AND LOSS. Bryla et al. (2012) measured the amount of nutrients accumulated and lost in a new planting of 'Bluecrop' northern highbush blueberry (Table 2). By the time the plants reached the first fruit harvest in the second year after planting, the plants acquired a total of $48.4,3.1,17.4,12.0,5.4$, and 8.4 $\mathrm{lb} /$ acre of $\mathrm{N}, \mathrm{P}, \mathrm{K}, \mathrm{Ca}, \mathrm{Mg}$, and $\mathrm{S}$, respectively; and 3.9, 0.6, 0.3, 17.6, and $0.9 \mathrm{oz} / \mathrm{acre}$ of $\mathrm{Fe}, \mathrm{B}, \mathrm{Cu}, \mathrm{Mn}$, and $\mathrm{Zn}$, respectively. About $7 \%$ to $52 \%$ of each nutrient was lost or removed from the planting through leaf senescence, pruning, and fruit harvest. Additional nutrients may have been lost to root turnover (Valenzuela-Estrada et al., 2008). An estimated $70 \%$ of the $\mathrm{N}$ in the plants at the end of the first year, and $25 \%$ of the $\mathrm{N}$ in the fruit the following year, was derived from fertilizer applied initially during the spring after planting (Bañados et al., 2012). It is likely that at least a portion of the $\mathrm{P}$ and $\mathrm{K}$ acquired by the plants was also 
derived from fertilizer, but no other nutrients were applied to the planting.

The total amount of nutrients removed during fruit harvest and pruning were also measured recently in mature plantings of northern highbush blueberry (B.C. Strik, unpublished data). Nutrient removal in the fruit differed among seven cultivars and was very much dependent on the yield (Table 3 ). The pruning losses were measured in Elliott, which tends to be a vigorous cultivar, often requiring more pruning than many others (Strik et al., 2014). Although the wood removed during pruning is usually flailed (chopped) between the rows, the plants do not typically have any roots between the rows. Hence, any nutrients that recycle into the soil after pruning are no longer available to the plants. On the basis of the estimated amount of nutrients contained in the fruit and prunings, a mature field that produces an average yield of 10 ton/acre will lose a total of 26-37 lb/acre N, 2.5-4.5 lb/acre P, 15-24 lb/acre K, 4-5 lb/acre Ca, $1.3-1.9 \mathrm{lb} /$ acre $\mathrm{Mg}, 1.7-3.1 \mathrm{lb} /$ acre $S$, 1.6-2.1 oz/acre Fe, $0.4-0.5 \mathrm{oz} /$ acre $\mathrm{B}$, $0.6-0.7 \mathrm{oz} / \mathrm{acre} \mathrm{Cu}, 12.5-13.1 \mathrm{oz} /$ acre $\mathrm{Mn}$, and $0.6-0.9 \mathrm{oz} / \mathrm{acre} \mathrm{Zn}$ per year. It is clear from these data that the nutrient demands associated with harvest and pruning are much lower than the amount of fertilizer applied to many plantings (Hanson and Hancock, 1996; Hart et al., 2006; Pritts and Hancock, 1992). Although additional nutrients are required for growth of new plant tissues and to replace any losses in other dry matter such as senesced leaves and roots, more research is needed to improve the efficiency of fertilizer applications in northern highbush blueberry.

LEAF NUTRIENT STANDARDS. Nutrient standards have been developed for northern highbush blueberry using results from research experiments and estimates from large databases that relate tissue nutrient levels to high-yielding fields (e.g., Hart et al., 2006). The standards are based on the analysis of the nutrients contained in recent, fully expanded leaves on shoots located below the fruiting zone when collected in late July to early August. Recently, tissue standards were reevaluated for western Oregon using leaf nutrient concentrations obtained from mature plants of six cultivars with different fruiting seasons (B.C. Strik, unpublished data). The cultivars included Duke, which, at the location of the study, ripens typically from mid-June to early July; Draper, which ripens in late June to mid-July; Bluecrop and Legacy, which ripen throughout July; Liberty, which ripens in mid to late July; and Aurora, which ripens from late July to late August (Strik et al., 2014). Each cultivar was grown in conventional and certified organic fields. Regardless of the cultivar and the fruiting season, best time to sample leaves for nutrient analysis was confirmed as late July to early August. However, there were significant differences among cultivars during this sampling period for many nutrients. For example, concentrations of $\mathrm{P}$, $\mathrm{K}, \mathrm{Ca}$, and $\mathrm{Cu}$ in the leaves were outside of the current recommendations (Hart et al., 2006). Although the present recommendations are to sample cultivars separately (Hart et al., 2006), and this has been confirmed (B.C. Strik, unpublished data), revised standards will be developed to account for broader variation among the newer cultivars that may result from differences in fruiting season and nutrient allocation. A tissue standard will be developed for these nutrients and will be added for aluminum (Al). Although $\mathrm{Al}$ is not an essential nutrient in northern highbush blueberry, low concentrations of $\mathrm{Al}$ in the leaves may indicate that soil $\mathrm{pH}$ is too

Table 2. Accumulation and loss of nitrogen $(\mathrm{N})$, phosphorus $(\mathrm{P})$, potassium $(\mathrm{K})$, calcium $(\mathrm{Ca})$, magnesium $(\mathrm{Mg})$, sulfur $(\mathrm{S})$, iron $(\mathrm{Fe})$, boron $(\mathrm{B})$, copper $(\mathrm{Cu})$, manganese $(\mathrm{Mn})$, and zinc $(\mathrm{Zn})$ in a new planting of 'Bluecrop' northern highbush blueberry in western Oregon (adapted from Bryla et al., 2012).

\begin{tabular}{|c|c|c|c|c|c|c|c|c|c|c|c|}
\hline \multirow[b]{2}{*}{ Activity period } & \multicolumn{6}{|c|}{ Macronutrients (lb/acre) $)^{y}$} & \multicolumn{5}{|c|}{ Micronutrients (oz/acre $)^{y}$} \\
\hline & $\mathbf{N}$ & $\mathbf{P}$ & $\mathbf{K}$ & $\mathrm{Ca}$ & $\mathrm{Mg}$ & $S$ & $\mathrm{Fe}$ & B & $\mathbf{C u}$ & Mn & $\mathbf{Z n}$ \\
\hline \multicolumn{12}{|l|}{ Accumulation } \\
\hline Bud break to harvest (year 2) & 30.3 & 1.8 & 11.1 & 5.7 & 3.0 & 4.9 & 0.9 & 0.33 & 0.28 & 11.1 & 0.44 \\
\hline \multicolumn{12}{|l|}{ Losses } \\
\hline Leaf senescence (year 1) & 8.3 & 0.4 & 4.2 & 2.7 & 0.6 & 1.5 & 1.5 & 0.14 & $<0.01$ & 0.9 & 0.01 \\
\hline
\end{tabular}

${ }^{2}$ Plants were fertilized each spring with $50 \mathrm{~kg} \cdot \mathrm{ha}^{-1} \mathrm{~N}$ from granular ammonium sulfate.

${ }^{\mathrm{y}} \mathrm{llb} / \mathrm{acre}=1.1209 \mathrm{~kg} \cdot \mathrm{ha}^{-1}, 1 \mathrm{oz} / \mathrm{acre}=70.0532 \mathrm{~g} \cdot \mathrm{ha}^{-1}$.

Table 3. Total amount of nitrogen $(\mathrm{N})$, phosphorus $(\mathrm{P})$, potassium $(\mathrm{K})$, calcium $(\mathrm{Ca})$, magnesium $(\mathrm{Mg})$, sulfur $(\mathrm{S})$, iron $(\mathrm{Fe})$, boron $(B)$, copper $(\mathrm{Cu})$, manganese $(\mathrm{Mn})$, and zinc $(\mathrm{Zn})$ removed during fruit harvest and winter pruning in a typical mature planting of northern highbush blueberry in western Oregon. ${ }^{\mathrm{z}}$

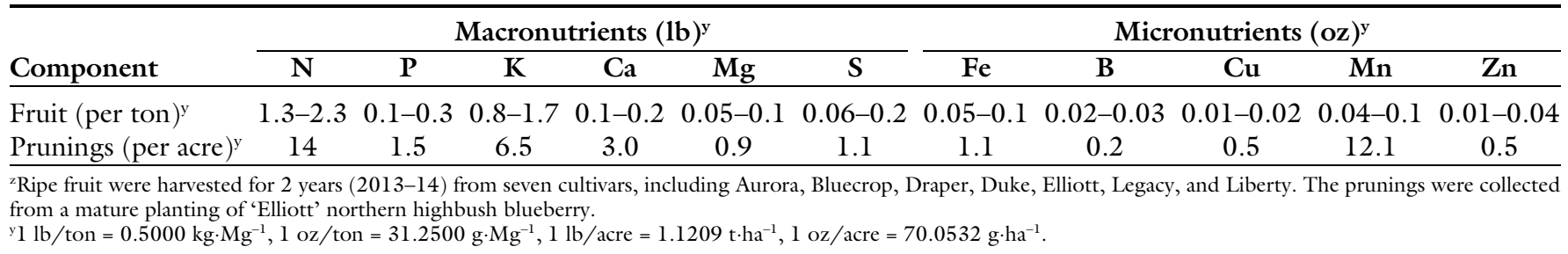


high, and high concentrations often indicate that $\mathrm{pH}$ is too low.

\section{Fertilizer products available for fertigation}

Nitrogen sources. As mentioned, blueberry requires primarily the $\mathrm{NH}_{4}$ form of $\mathrm{N}$. Common sources of $\mathrm{NH}_{4}$ or $\mathrm{NH}_{4}$-forming fertilizers available for fertigation include:

Ammonium nitrate solution $\left[\mathrm{NH}_{4} \mathrm{NO}_{3} \cdot \mathrm{H}_{2} \mathrm{O}(20 \mathrm{~N}-0 \mathrm{P}-0 \mathrm{~K})\right]$ or AN-20 is commonly used for fertigation in many fruit and vegetable crops. However, it is not recommended for blueberry due to the high concentration of $\mathrm{NO}_{3}-\mathrm{N}(50 \%$ of total $\mathrm{N})$ in the solution.

Ammonium polyphosphate $\left[\left(\mathrm{NH}_{4} \mathrm{PO}_{3}\right)_{\mathrm{n}}(10 \mathrm{~N}-34 \mathrm{P}-0 \mathrm{~K}\right.$ or $11 \mathrm{~N}-$ $37 \mathrm{P}-0 \mathrm{~K})$ ] contains $10 \%$ to $11 \% \mathrm{NH}_{4}$ $\mathrm{N}$ but is used primarily as a source of phosphorus nutrition. Polyphosphate reverts quickly to monophosphate (only form of $\mathrm{P}$ taken up by plants) in acidic environments and, therefore, is readily available for uptake by blueberry. It is widely used to make a variety of fertilizer solutions. The fertilizer forms highly insoluble calcium pyrophosphates when injected into irrigation water with high calcium and high carbonate/bicarbonate contents and, therefore, may severely plug the drip emitters when used under these conditions.

Ammonium sulfate $\left[\left(\mathrm{NH}_{4}\right)_{2} \mathrm{SO}_{4}\right]$ is probably the most common source of $\mathrm{N}$ applied to blueberry as a granular fertilizer and is available in the liquid form (8N-0P-0K-9S). Solutions can be made using dry, granular ammonium sulfate $(21 \mathrm{~N}-$ $0 \mathrm{P}-0 \mathrm{~K}-24 \mathrm{~S}$ ), which dissolves in water at a maximum solubility of $6.3 \mathrm{lb} / \mathrm{gal}$ at $70^{\circ} \mathrm{F}$.

Ammonium thiosulfate $\left[\left(\mathrm{NH}_{4}\right)_{2}\right.$ $\left.\mathrm{S}_{2} \mathrm{O}_{3}(12 \mathrm{~N}-0 \mathrm{P}-0 \mathrm{~K}-26 \mathrm{~S})\right]$ is typically used as an acidulating agent but could also serve as potential $\mathrm{N}$ source for blueberry plants growing in high $\mathrm{pH}$ soils $(>6.5)$. Although this product has not been tested scientifically in blueberry, several growers are currently using it for fertigation in commercial northern highbush blueberry fields in western United States (D.R. Bryla, personal observations).

Calcium ammonium nitrate $[\mathrm{Ca}$ $\left(\mathrm{NO}_{3}\right)_{2} \cdot \mathrm{NH}_{4} \mathrm{NO}_{3} \quad(17 \mathrm{~N}-0 \mathrm{P}-0 \mathrm{~K}-$ 8.8Ca)] or CAN-17 is high in $\mathrm{NO}_{3}-\mathrm{N}$, low in $\mathrm{NH}_{4}-\mathrm{N}$, and supplies calcium.
Certain crops such as strawberry (Fragaria $\times$ ananassa) and raspberry (Rubus idaeus) appear to produce higher quality fruit when fertilized with CAN-17. However, like ammonium nitrate solution, the fertilizer is too high in $\mathrm{NO}_{3}-\mathrm{N}$ for practical application in blueberry.

Urea solution $\left[\left(\mathrm{NH}_{2}\right)_{2} \mathrm{CO}(20 \mathrm{~N}-\right.$ $0 \mathrm{P}-0 \mathrm{~K}$ or $23 \mathrm{~N}-0 \mathrm{P}-0 \mathrm{~K})]$ is also commonly used for fertigation in northern highbush blueberry, particularly when soil $\mathrm{pH}<5.0$. Urea rapidly converts to $\mathrm{NH}_{4}-\mathrm{N}$ in the soil but is less acidifying than ammonium fertilizers (Fig. 1). It is also less costly per unit $\mathrm{N}$ and can be made as a weaker dilution by mixing granular urea $[46 \mathrm{~N}-0 \mathrm{P}-0 \mathrm{~K}$ (another fertilizer commonly used for granular applications in blueberry)] in water at a maximum solubility of $8.8 \mathrm{lb} / \mathrm{gal}$ at $70^{\circ} \mathrm{F}$. Note that the solution will become extremely cold as the fertilizer dissolves. Some growers are currently combining urea and ammonium sulfate solutions to create a custom liquid fertilizer blend $(20 \mathrm{~N}-0 \mathrm{P}-0 \mathrm{~K}-5 \mathrm{~S})$ for northern highbush blueberry.

Urea-ammonium nitrate solution $\left[\left(\mathrm{NH}_{2}\right)_{2} \mathrm{CO} \cdot \mathrm{NH}_{4} \mathrm{NO}_{3}(32 \mathrm{~N}-0 \mathrm{P}-0 \mathrm{~K})\right]$ or UN-32 (UAN-32) is manufactured by combining urea $(46 \% \mathrm{~N})$ and ammonium nitrate $(35 \% \mathrm{~N})$. Of the available $\mathrm{N}$ sources, ureaammonium nitrate has the highest $\mathrm{N}$ concentration. It is marketed as a $32 \% \mathrm{~N}$ solution in warmer agricultural climates and as a $28 \% \mathrm{~N}$ solution in cooler agricultural areas. Urea-ammonium nitrate solution forms a thick, milky-white insoluble precipitate when combined with CAN-17 or other calcium nitrate solutions, which could also cause serious plugging problems.

Urea sulfuric acid $\left[\mathrm{CO}\left(\mathrm{NH}_{2}\right)_{2}\right.$. $\left.\mathrm{H}_{2} \mathrm{SO}_{4}\right]$ is an acidic combination of urea and sulfuric acid. Mixing the two products is extremely exothermic (explosive reaction if the temperature is not controlled) and should not be attempted under normal atmospheric conditions. Combining the two materials eliminates many of the disadvantages of using them individually. The sulfuric acid decreases the potential for volatilization losses from the soil surface and ammonia damage in the root zone, while including urea with the sulfuric acid is much safer than sulfuric acid alone. This product is commonly sold under various formulations of $\mathrm{N}$ and sulfuric acid such as $10 / 55 \quad(10 \% \mathrm{~N}$ and $55 \%$ sulfuric acid), 15/49 (15\% $\mathrm{N}$ and $49 \%$ sulfuric acid), and 28/27 (28\% $\mathrm{N}$ and $27 \%$ sulfuric acid).

For organic production, we successfully fertigated a certified field of northern highbush blueberry plants with fish emulsion and used the product as the sole nutrient source of fertilizer for 8 years (B.C. Strik, unpublished data). The fertilizer was particularly effective during establishment and contained $\approx 4 \% \mathrm{~N}$ and substantial amounts of other nutrients, including $\mathrm{P}, \mathrm{K}$, and $\mathrm{Mg}$ (Larco et al., 2013a, 2013b). Several organically approved liquid fertilizers are available for fertigation, including nonfish products such as corn steep liquor; these products mineralize rapidly within a few weeks but vary considerably in the cost per pound of actual $\mathrm{N}$ applied (Mikkelsen and Hartz, 2008; Miles et al., 2010). When fertigating with organic fertilizers, dilute the product before injection to lower the viscosity, and flush the drip lines at least annually to reduce emitter plugging (Fernandez-Salvador et al., 2015).

SoIL SUPPLEMENTs. In addition to applying nutrient solutions, several blueberry growers in the United States and elsewhere are incorporating humic acids (also known as organic acids) into their fertilizer programs. Humic and fulvic acids (lower molecular weight and higher oxygen content than other humic acids) are commonly used as soil supplements and have been found to stimulate plant growth in several crops (Nardi et al., 2002; Rose et al., 2014; Varanini and Pinton,

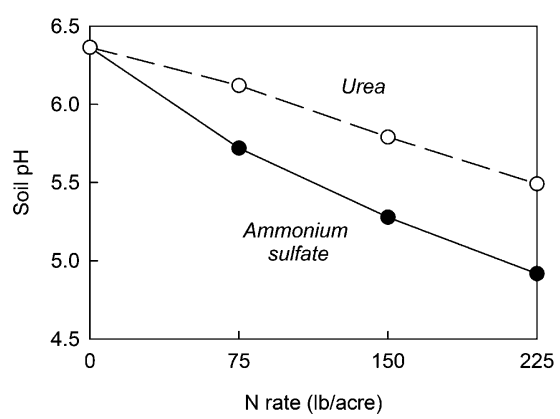

Fig. 1. Average soil $\mathrm{pH}$ in a 'Bluecrop' northern highbush blueberry field following 5 years of fertigation at different nitrogen $(N)$ rates with ammonium sulfate or urea (adapted from Vargas and Bryla, 2015); $1 \mathrm{lb} /$ acre $=1.1209 \mathrm{~kg} \cdot \mathrm{ha}^{-1}$. 
2001), including northern highbush blueberry (Bryla and Vargas, 2014). Reported benefits of these substances include improved soil properties and structure, greater bioavailability of soil nutrients, increased microbial populations, and plant hormone-like effects (Chen et al., 2004a, 2004b; Morard et al., 2011; Muscolo et al., 2013; Piccolo and Mbagwu, 1989). Root growth was particularly enhanced by humic acids during the first 2 years after planting a new field of 'Draper' northern highbush blueberry (Fig. 2). More work is underway in our group to determine if humic acids are also beneficial to growth and fruit production in mature plants.

Injection of sulfuric acid $\left(\mathrm{H}_{2} \mathrm{SO}_{4}\right)$ into the irrigation water has also
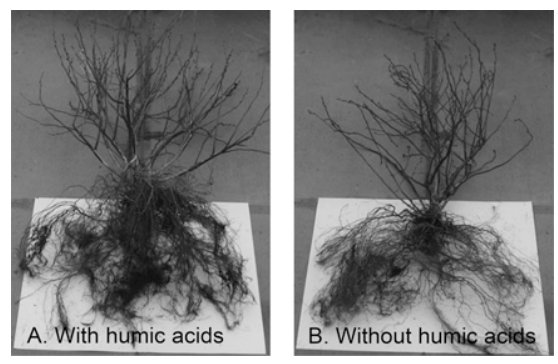

Fig. 2. 'Draper' northern highbush blueberry plants grown (A) with or (B) without humic acids. The plants were grown in a field in western Oregon and destructively harvested following the second year after planting (2012). Shoot and root dry weight averaged 651 and $349 \mathrm{~g}$, respectively, with humic acids, and 561 and $246 \mathrm{~g}$, respectively, without humic acids; $1 \mathrm{~g}=$ $0.0353 \mathrm{oz}$ (images courtesy of O.L. Vargas).

become a popular practice in regions with high soil $\mathrm{pH}$ and/or a high percentage of carbonates $\left(\mathrm{CO}_{3}\right)$ and bicarbonates $\left(\mathrm{HCO}_{3}\right)$ in the irrigation water, such as California and eastern Oregon and Washington. Because acid materials are hazardous and highly corrosive, several growers now use sulfur dioxide $\left(\mathrm{SO}_{2}\right)$ generators, often referred to as "sulfur burners," in place of acid injectors for acidifying the irrigation water and reducing soil $\mathrm{pH}$. Elemental sulfur burned in the generators is converted to sulfurous acid $\left(\mathrm{H}_{2} \mathrm{SO}_{3}\right)$ and mixed with the irrigation water to lower the $\mathrm{pH}$. Sulfur burners are certified for organic production. Other options for acidifying the water in organic systems include injection of acetic or citric acid.

\section{Drip line placement}

Although $\mathrm{NO}_{3}-\mathrm{N}$ is very mobile and moves readily in moist soil to plant roots, $\mathrm{NH}_{4}-\mathrm{N}$ moves much more slowly, often advancing only $1-2$ inches over several months (Barber, 1995). Therefore, the $\mathrm{N}$ in $\mathrm{NH}_{4}$ fertilizers will only be available to the plants when the fertilizer is applied close to the roots (Vargas et al., 2015). Any of the fertilizer that is applied away from the roots is likely to convert to $\mathrm{NO}_{3}-\mathrm{N}$, through a process of nitrification, and eventually will be leached from the field by rain or irrigation (Haynes, 1990). On most soil types, only one line of drip tubing per row is needed for adequate irrigation of northern highbush blueberry, but two lines per row is often used to encourage a larger root system and increase

Table 4. Effects of a preplant application of nitrogen $(\mathrm{N})$ fertilizer on shoot and root dry weight, leaf $\mathrm{N}$ concentration, and yield of 'Draper' northern highbush blueberry in western Oregon. ${ }^{z}$

\begin{tabular}{|c|c|c|c|c|}
\hline \multirow{2}{*}{$\begin{array}{l}\text { Nitrogen fertilizer } \\
\text { incorporated into the } \\
\text { field before planting }\end{array}$} & \multicolumn{2}{|c|}{ Plant dry wt (g/plant $)^{x}$} & \multirow{2}{*}{$\begin{array}{c}\text { Leaf } \\
\mathbf{N}(\%)^{\mathrm{w}}\end{array}$} & \multirow{2}{*}{$\begin{array}{c}\text { Yield } \\
\text { (lb/plant })^{\mathrm{v}}\end{array}$} \\
\hline & Shoot & Root & & \\
\hline Yes & 591 & 241 & 1.67 & 1.4 \\
\hline No & 588 & 221 & 1.61 & 1.6 \\
\hline Difference $^{u}$ & $3^{\mathrm{Ns}}$ & $20^{\mathrm{Ns}}$ & $0.06^{\mathrm{Ns}}$ & $0.2^{\mathrm{Ns}}$ \\
\hline
\end{tabular}

${ }^{2}$ The plants were grown on raised beds with 19 units/acre of incorporated fresh sawdust (3.5 inches deep in 3 -ftwide bands on 10 - $\mathrm{ft}$ centers to a depth of 10 inches) and 11 units/acre ( 2 inches deep in 3 -ft-wide bands on 10 - $\mathrm{ft}$ centers $)$ of fresh sawdust mulch; 1 unit of sawdust $=200 \mathrm{ft}^{3}\left(5.6634 \mathrm{~m}^{3}\right), \mathrm{l}$ unit $/$ acre $=2.471 \mathrm{lunits} / \mathrm{ha}, \mathrm{l}$ inch $=$ $2.54 \mathrm{~cm}, \mathrm{l} \mathrm{ft}=0.3048 \mathrm{~m}$

${ }^{\mathrm{y}}$ Granular ammonium sulfate was either incorporated along with the sawdust at a rate of $95 \mathrm{lb} / \mathrm{acre}\left(106.5 \mathrm{~kg} \cdot \mathrm{ha}^{-1}\right)$ $\mathrm{N}$ or was not incorporated at all before planting. Irrigation was applied using two lines of drip per row, and liquid urea was injected (April-July) through the drip system at annual rate of $100 \mathrm{~kg} \cdot \mathrm{ha}^{-1}(89.2 \mathrm{lb} / \mathrm{acre}) \mathrm{N}$ per year.

${ }^{x}$ The plants were destructively harvested in Oct. 2012, following the second year after planting; $1 \mathrm{~g}=0.0353 \mathrm{oz}$. weaf samples were collected in early Aug. 2012, during the second year after planting.

vPlants were lightly cropped during the second year after planting and harvested in July $2012 ; 1 \mathrm{lb}=0.4536 \mathrm{~kg}$.

"Difference between the means were compared by analysis of variance.

Nonignificant $(P>0.05)$. plant access to soil nutrients (Ehret et al., 2012). The lines are often located near the base of the plants during the first or second year after planting and later repositioned 6-12 inches on each side of the plants as the root system develops. Installing the drip lines under weed mat or burying them under sawdust mulch helps to secure the lines in place, prevents any damage during winter pruning, and reduces water runoff on raised beds.

Since only a fraction of the soil is wetted by the drip emitters, most of the $\mathrm{N}$ applied to the plants during fertigation is added directly to the region of the soil where many of the roots are concentrated. As a result, extra $\mathrm{N}$ is not required with fertigation when sawdust or pine bark is incorporated into the soil before planting or used as mulch (Table 4). This is in contrast to using granular fertilizers, which requires an extra 25 $\mathrm{lb} / \mathrm{acre}$ of $\mathrm{N}$ when 2-3 inches of fresh sawdust is used as a mulch (Hart et al., 2006).

\section{Timing and rate of nitrogen fertigation}

Liquid fertilizers should be injected in small and frequent applications (e.g., once per week), starting at leaf emergence and finishing in late July or early August. Fertigation is not recommended for the entire growing season (e.g., April-September) because $\mathrm{N}$ applications in late summer reduce flower bud development in northern highbush blueberry and may lead to late flushes of growth that increase the potential for freeze damage over the winter (Caruso and Ramsdell, 1995).

In western Oregon and Washington, many growers using drip irrigation apply granular fertilizers in March or April and then, once irrigation is required on a regular basis, switch to fertigation in May (D.R. Bryla, personal observations). The use of granular fertilizer in the spring is less expensive than fertigation and practical for use in mature plants, provided weed mat (geotextile fabric) is not used or is opened before application. However, it may cause fertilizer "burn" (salt damage to shoots and roots from the fertilizer) in new plantings and, in severe cases, can kill young plants (Bañados et al., 2012; Bryla and Machado, 
2011). Even small applications of granular ammonium sulfate applied at a rate of $20 \mathrm{~kg} \cdot \mathrm{ha}^{-1} \mathrm{~N}$ in the spring, before fertigation, reduced shoot growth and caused root damage in young 'Draper' plants (Fig. 3).

The recommended $\mathrm{N}$ rates for fertigation are shown in Table 5 . The rates are higher than those recommended for granular fertilizers in

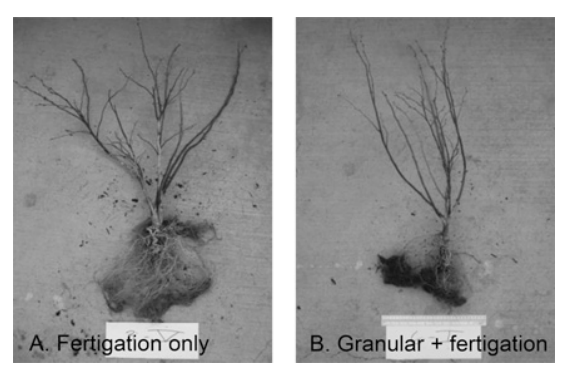

Fig. 3. 'Draper' northern highbush blueberry plants fertilized (A) by fertigation once per week from midApril to the end of July with a total of $100 \mathrm{~kg} \cdot \mathrm{ha}^{-1}$ nitrogen $(\mathrm{N})$ or $(\mathrm{B})$ with two small granular fertilizer applications of $10 \mathrm{~kg} \cdot \mathrm{ha}^{-1} \mathrm{~N}$ each in mid-April and mid-May followed by fertigation once per week in June and July with an additional $80 \mathrm{~kg} \cdot \mathrm{ha}^{-1} \mathrm{~N}$. The plants were grown in a field in western Oregon and destructively harvested following the first year after planting (2011). Shoot and root dry weight averaged 162 and $65 \mathrm{~g}$, respectively, with fertigation only, and 112 and $58 \mathrm{~g}$, respectively, with the combination of granular fertilizer and fertigation; $1 \mathrm{~kg} \cdot \mathrm{ha}^{-1}=0.8922 \mathrm{lb} /$ acre, $1 \mathrm{~g}=0.0353 \mathrm{oz}$ (images courtesy of O.L. Vargas).
Oregon and British Columbia during the first 2 years after planting but are similar to the granular rates in the following years (British Columbia Ministry of Agriculture, 2014; Hart et al., 2006). Higher $\mathrm{N}$ rates are recommended initially for fertigation due to low application efficiency in young plantings (Bryla and Machado, 2011). Many growers using drip irrigation install drip tubing or drip tape with in-line emitters spaced every 12 or 18 inches. Since the plants are usually spaced 2.5-3 ft apart, roughly half of the emitters end up between the plants and outside of the root zone. Consequently, much of the $\mathrm{NH}_{4}-\mathrm{N}$ is unavailable for a year or so, until which time the root systems grow large enough to reach the emitters between the plants (Vargas et al., 2015). In contrast, granular fertilizer is often applied by hand directly around the base of plants (within the drip line of the bush) during the first or second year after planting (Hart et al., 2006).

By the third year after planting, less $\mathrm{N}$ is needed with fertigation because most of the $\mathrm{N}$ at this point is applied directly to the root zone and is no longer lost between the plants (Vargas et al., 2015). The $\mathrm{N}$ is also injected in small and frequent applications during fertigation, which is much more efficient than using two or three large applications of granular fertilizer. For example, Machado et al. (2014) measured $\mathrm{NH}_{4}-\mathrm{N}$ in the soil solution in a 3-year-old planting of 'Bluecrop' northern highbush blueberry and found that concentrations increased to $800-1500 \mathrm{ppm}$

Table 5. Recommended nitrogen $(\mathrm{N})$ rates for northern highbush blueberry.

\begin{tabular}{lccc}
\hline & \multicolumn{3}{c}{ Recommended N rate (lb/acre) } \\
\cline { 2 - 4 } Yr & Fertigation & Oregon $^{\mathrm{y}}$ & Granular fertilizer $^{\text {British Columbia }}$ \\
\hline 1 & 90 & $25-40^{\mathrm{w}}$ & 19 \\
2 & 90 & $40-50^{\mathrm{w}}$ & 27 \\
3 & 60 & $50-60$ & 45 \\
4 & 70 & $55-65$ & 50 \\
5 & 75 & $65-75$ & 65 \\
6 & 85 & $80-100$ & 70 \\
7 & 95 & $90-120$ & 90 \\
$8+$ & $100-150$ & $100-140$ & 100 \\
\hline
\end{tabular}

${ }^{2}$ On the basis of an in-row plant spacing of 2.5-3.0 ft $(0.76-0.91 \mathrm{~m}) ; \mathrm{l} \mathrm{lb} / \mathrm{acre}=1.1209 \mathrm{~kg} \cdot \mathrm{ha}^{-1}$

'Modified from Hart et al. (2006) for a field without sawdust mulch. The rates assume that the plant canopies will be touching by Year 3 . If sawdust mulch is used and replenished every 3 years, add $25 \mathrm{lb} /$ acre $\mathrm{N}$ to the recommended granular rate.

${ }^{x}$ From British Columbia Ministry of Agriculture (2014)

wThe granular rates for the first 2 years in Oregon assume that the fertilizer is applied by hand in a circular pattern along the drip line of the plants. If a fertilizer spreader is used, then increase these rates to account for lower application efficiency.

following each of three applications of granular ammonium sulfate, but remained $\leq 10 \mathrm{ppm}$ throughout the season when the fertilizer was applied once a week from mid-April to midAugust by drip fertigation. Fertigation, in this case, also resulted in more vegetative growth, greater yield, and higher leaf $\mathrm{N}$ concentrations, and therefore, was more efficient than using the granular fertilizer, now that the plants were larger.

\section{Future directions for research}

Avenues for future research on nutrient management in blueberry include fertigation with other nutrients besides $\mathrm{N}$ and more work on soil supplements such as humic and fulvic acids. The information is needed to identify the best sources of each nutrient and to determine the best time and rate to apply them. The use of humic and fulvic acids appears promising for blueberry, but the mechanism(s) of their effect on root growth and whether they increase fruit production remains unclear. Possible mechanisms include increased availability of soil nutrients and chelation of micronutrients, enhanced water penetration and retention, stimulated beneficial microbial activity, and induced hormonal effects on root growth. Research is also needed to determine the implications of new soil management practices such as use of landscape fabric (weed mat) for weed control on root growth and root function and the effects it might have on the availability of soil nutrients.

\section{Literature cited}

Abbott, J.D. and R.E. Gough. 1987. Seasonal development of highbush blueberry roots under sawdust mulch. J. Amer. Soc. Hort. Sci. 112:60-62.

Bañados, M.P., B.C. Strik, D.R. Bryla, and T.L. Righetti. 2012. Response of highbush blueberry to nitrogen fertilizer during field establishment. I: Accumulation and allocation of fertilizer nitrogen and biomass. HortScience 47:648-655.

Barber, S.A. 1995. Soil nutrient bioavailability. 2nd ed. Wiley, New York, NY.

British Columbia Ministry of Agriculture. 2014. 2014 Berry production guideBeneficial management practices for berry growers in British Columbia. British Columbia Ministry Agr., Victoria, British Columbia, Canada. 
Bryla, D.R. 2011. Application of the "4R" nutrient stewardship concept to horticultural crops: Getting nutrients in the "right" place. HortTechnology 21: 674-682.

Bryla, D.R. and B.C. Strik. 2007. Effects of cultivar and plant spacing on the seasonal water requirements of highbush blueberry. J. Amer. Soc. Hort. Sci. 132:270-277.

Bryla, D.R., B.C. Strik, M.P. Bañados, and T.L. Righetti. 2012. Response of highbush blueberry to nitrogen fertilizer during field establishment. II. Plant nutrient requirements in relation to nitrogen fertilizer supply. HortScience 47:917926.

Bryla, D.R. and O. Vargas. 2014. Nitrogen fertilizer practices for rapid establishment of highbush blueberry: A review of six years of research. Acta Hort. 1017: $415-421$

Bryla, D.R. and R.M.A. Machado. 2011. Comparative effects of nitrogen fertigation and granular fertilizer application on growth and availability of soil nitrogen during establishment of highbush blueberry. Front. Plant Sci. 2:46, doi: 10.3389/ fpls.2011.00046.

Caruso, F.L. and D.C. Ramsdell. 1995. Compendium of blueberry and cranberry diseases. APS Press, St. Paul, MN

Chen, Y., C.E. Clapp, and H. Magen. 2004a. Mechanisms of plant growth stimulation by humic substances: The role of organo-iron complexes. Soil Sci. Plant Nutr. 50:1089-1095.

Chen, Y., M. De Nobili, and T. Aviad. 2004 b. Stimulatory effects of humic substances on plant growth, p. 103-129. In: F. Magdoff and R.R. Weil (eds.). Soil organic matter in sustainable agriculture. CRC Press, Boca Raton, FL.

Ehret, D.L., B. Frey, T. Forge, T. Helmer, and D.R. Bryla. 2012. Effects of drip irrigation configuration and rate on yield and fruit quality of young highbush blueberry plants. HortScience 47:414421.

Ehret, D.L., B. Frey, T. Forge, T. Helmer, D.R. Bryla, and B.J. Zebarth. 2014. Effects of nitrogen rate and application method on early production and fruit quality in highbush blueberry. Can. J. Plant Sci. 94:1165-1179.

Fernandez-Salvador, J., B.C. Strik, and D.R. Bryla. 2015. Liquid corn and fish fertilizers are good options for fertigation in blackberry cultivars grown in an organic production system. HortScience 50:225-233.

Hanson, E.J. and J.B. Hancock. 1996. Managing the nutrition of highbush blueberries. Michigan State Univ. Ext. Bul. Publ. E-2011.

Hart, J., B. Strik, L. White, and W. Yang. 2006. Nutrient management for blueberries in Oregon. Oregon State Univ. Ext. Serv. Publ. EM 8918.

Haynes, R.J. 1990. Movement and transformations of fertigated nitrogen below trickle emitters and their effects on $\mathrm{pH}$ in the wetted soil volume. Nutr. Cycl. Agroecosyst. 23:105-112.

Kafkafi, U. and J. Tarchitsky. 2011. Fertigation. A tool for efficient fertilizer and water management. Intl. Fert. Ind. Assn., Paris, France/Intl. Potash Inst., Horgen, Switzerland.

Korcak, R.F. 1988. Nutrition of blueberry and other calcifuges. Hort. Rev. 10:183227.

Larco, H., B.C. Strik, D.R. Bryla, and D.M. Sullivan. 2013a. Mulch and fertilizer management practices for organic production of highbush blueberry. I: Plant growth and allocation of biomass during establishment. HortScience 48:1250-1261.

Larco, H., B.C. Strik, D.R. Bryla, and D.M. Sullivan. 2013b. Mulch and fertilizer management practices for organic production of highbush blueberry. II: Impact on plant and soil nutrients during establishment. HortScience 48:1484-1495.

Machado, R.M.A., D.R. Bryla, and O. Vargas. 2014. Effects of salinity induced by ammonium sulfate fertilizer on root and shoot growth in highbush blueberry. Acta Hort. 1017:407-414.

Merhaut, D. and R. Darnell. 1995. Ammonium and nitrate accumulation in containerized southern highbush blueberry plants. HortScience 30:1378-1381.

Mikkelsen, R. and T.K. Hartz. 2008. Nitrogen sources for organic crop production. Better Crops 92:16-19.

Miles, C., J. Roozen, E. Maynard, and T. Coolong. 2010. Fertigation in Organic Vegetable Production Systems. eOrganic and eXtension. 4 May 2015. <http://www.extension.org/pages/ 29712/fertigation-in-organic-vegetableproduction-systems $>$.

Morard, P., B. Eyheraguibel, M. Morard, and J. Silvestre. 2011. Direct effects of humic-like substance on growth, water, and mineral nutrition of various species. J. Plant Nutr. 34:46-59.

Muscolo, A., M. Sidari, and S. Nardi. 2013. Humic substance: Relationship between structure and activity. Deeper information suggests univocal findings. J. Geochem. Explor. 129:57-63.
Nardi, S., D. Pizzeghello, A. Muscolo, and A. Vianello. 2002. Physiological effects of humic substances on higher plants. Soil Biol. Biochem. 34:15271536.

Peterson, L.A., E.J. Stang, and M.N. Dana. 1988. Blueberry response to $\mathrm{NH}_{4}{ }^{+}$$\mathrm{N}$ and $\mathrm{NO}_{3}^{-}-\mathrm{N}$. J. Amer. Soc. Hort. Sci. 113:9-12.

Piccolo, A. and J.S.C. Mbagwu. 1989. Effects of humic substances and surfactants on the stability of soil aggregates. Soil Sci. 147:47-54.

Pritts, M.P. and J.F. Hancock. 1992. Commercial blueberry production guide. Northeast Regional Coop. Eng. Serv., Ithaca, NY, NRAES-55.

Rose, M.T., A.F. Patti, K.R. Little, A.L. Brown, W.R. Jackson, and T.R. Cavagnaro. 2014. A meta-analysis and review of plantgrowth response to humic substances: Practical implications for agriculture. Adv. Agron. 124:37-89.

Strik, B.C., C.E. Finn, and P.P. Moore. 2014. Blueberry cultivars for the Pacific Northwest. Pacific Northwest Ext. Publ. PNW 656.

Strik, B.C. and G. Buller. 2005. The impact of early cropping on subsequent growth and yield of highbush blueberry in the establishment years at two planting densities is cultivar dependent. HortScience 40:1998-2001.

Valenzuela-Estrada, L.R., V. Vera-Caraballo, L.E. Ruth, and D.M. Eissenstat. 2008. Root anatomy, morphology, and longevity among root orders in Vaccinium corymbosum (Ericaceae). Amer. J. Bot. 95:1506-1514.

Varanini, Z. and R. Pinton. 2001. Direct versus indirect effects of soil humic substances on plant growth and nutrition, p. 141-158. In: R. Pinton, Z. Varanini, and P. Nannipieri (eds.). The rhizosphere. Biochemistry and organic substances at the soil-plant interface. Marcel Dekker, New York, NY.

Vargas, O.L. and D.R. Bryla. 2015. Growth and fruit production of highbush blueberry fertilized with ammonium sulfate and urea applied by fertigation or as granular fertilizer. HortScience 50:479485 .

Vargas, O.L., D.R. Bryla, J.E. Weiland, B.C. Strik, and L. Sun. 2015. Irrigation and fertigation with drip and alternative micro irrigation systems in northern highbush blueberry. HortScience 50:897903. 